\title{
Death Analysis of 10 Major Diseases Before and During COVID-19 Pandemic in Papua Province, Indonesia, 2020
}

\author{
Hasmi $^{1}$, Dolfinus Y. Bouway ${ }^{2}$, Yacob Ruru ${ }^{3}$ \\ ${ }^{1}$ Associate Professor, ${ }^{2}$ Assistant Professor, Department of Epidemiology, Faculty of Public Health, Cenderawasih \\ University, Jayapura, Papua, Indonesia, ${ }^{3}$ Assistant Professor, Department of Statistics, Faculty of Mathematics \\ and Natural Sciences, Cenderawasih University, Jayapura, Papua, Indonesia
}

\begin{abstract}
Some of the co-morbidities that may cause death in COVID-19 patients include: hypertension, diabetes, lung disease, heart disease and malaria. People with the disease have a high death rate when they become infected with COVID-19. The aim of this study is to analyze the deaths of the top 10 diseases in the Papua Province prior to and during the COVID-19 pandemic. The research method used in this study is a mix method. The research was conducted in Papua Province and Yowari Regional Hospital, Jayapura Regency, from September to November 2020. The informants were the Head of the Provincial Health Office and three heads of the COVID-19 epicenter of the Health Office. Quantitative samples were taken from patients who died between January 2020 and June 2020, namely 87 cases of death. A sample of 87 people was obtained using a total sampling technique. Data gathering techniques are secondary data and in-depth interviews. The results showed an increase in the number of deaths in the top 10 diseases before and during COVID-19, with an increase of 71 percent. The cause of the increase in death rates before and during the COVID-19 pandemic was due to a misconception of health and illness, as well as to the behavior of people who were late to go to health services. Death from heart failure was the main cause of death. At Yowari Regional Hospital, Jayapura Regency, people who died from the top 10 diseases before COVID-19 were aged 26-45 years, i.e. 11 people (34.4 percent). Meanwhile, the majority were 46-65 years old during the COVID-19 pandemic, i.e. 18 people (32.7 percent). Promotional and preventive efforts are the strategy of the local government (Health Department) to reduce deaths from the top 10 diseases during the COVID-19 pandemic.
\end{abstract}

Keywords: Cause of death, 10 major diseases, COVID-19 pandemic

\section{Introduction}

To become a pandemic, WHO has increased the status of COVID-19 internationally, while its status has become a non-natural National Disaster in Indonesia. Corona virus infections have spread to 34 provinces in

\section{Corresponding author:}

\section{Hasmi,}

Associate Professor, Department of Epidemiology, Faculty of Public Health, Cenderawasih University, Jl. Raya Abepura Sentani, Gedung Baru FKM Uncen, Jayapura, Papua, Indonesia. Email: hasmiuncen20@ gmail.com, Mobile: +6285244617411
Indonesia, with a total of 54,010 cases of COVID-19 virus infections as of 28 June $2020 .{ }^{1}$ The World Health Organization (WHO) declared a new virus named "COVID-19" on February 11, 2020. The first COVID-19 case outside China was reported in Thailand on January $13,2020 .^{2}$

As of 1 July 2020, as many as 104,000 confirmed cases were registered in Indonesia with the incidence of corona virus sufferers; 62,138 people recovered and 4,975 died. $^{2}$ TB (11,699 individuals or 3.6 per 1,000 population), HIV (16,980 individuals or 5.3 per 1,000 population), AIDS (26,295 individuals or 8.2 per 1,000 population), malaria ( 16,980 or 5.3 per 1,000 population) $(214,917$ people or 67.1 percent). Infant malnutrition 
(10.9 percent), malnutrition (1.49 percent), and poor safe and clean lifestyle (47.2 percent). ${ }^{3}$

Patients that are positively infected with coronary virus (COVID-19) may have serious and aggravating symptoms if they have co-morbidities and approximately $80 \%$ of cases lead to mild infections. Many individuals have the disease in many cases and do not exhibit symptoms. This is what makes it harder to regulate COVID-19. ${ }^{4}$

There are several co-morbidities that may cause death in COVID-19 patients. Complementary diseases worsen the clinical course of COVID-19 because immunity is lower, especially if the number of factors is not properly controlled. Some of the co-morbidities that may cause death in COVID-19 patients include: hypertension, diabetes, lung disease, heart disease, and dengue fever. People with concomitant diseases are at high risk of dying when they become infected with COVID-19. ${ }^{5}$

Based on this information, it is shown that the increased mortality rate during the COVID-19 pandemic is one of the reasons for the co-morbidity of patients or patients infected with this virus. It is known that there are 10 most contagious and non-contagious diseases in Indonesia that still occur and can cause death.

Examining the current situation, where an epidemic that could be said to be dangerous in Indonesia, particularly Papua in 2020, is the Corona/COVID-19 virus. The fact is that there are still the top 10 diseases that need further treatment as well. It can be said, therefore, that the duties and responsibilities of medical officers are very heavy and that they are always required to work more exceptionally and to be guided by all work procedures.
In 2019, there were 149 cases of raw death reported at the Yowari Regional General Hospital, including the types of diseases: tuberculosis, Stroke, diabetes mellitus, anemia, acute diarrhea, malaria, HIV/AIDS, and tetanus disease. $^{6}$

There were 87 cases of crude death reported at the Yowari Regional General Hospital until June 2020. Top 10 diseases consisting of: Heart Failure (Death on Arrival), Pulmonary TB, Decreased Consciousness, Acute Diarrhea, Hypovolemic Shock, Malaria, Hepatitis Synosis, Bronchopneumonia, Hypertension, and Hemorrhagic Shock. $^{6}$

This study was conducted to analyze the changes that occurred in the number of deaths caused by the top 10 diseases, whether or not the COVID-19 virus had a major impact on the disease, both infectious and noncontagious.

\section{Materials and Method}

This type of research is a mixed method conducted in Papua Province and at Yowari Regional Hospital, Jayapura Regency from September to November 2020. Informants were the Head of the Provincial Health Office, and 3 heads of the COVID-19 epicenter of the Health Office. The quantitative sample was patients who died in January to June 2020, namely 87 cases of death. With a total sampling technique, a sample of 87 people was obtained. Data collection techniques are secondary data analysis and in-depth interviews.

\section{Findings}

The results of the quantitative data at Yowari Regional Hospital showed an increase of $71 \%$ from 32 cases of death before the pandemic to 55 deaths during the COVID-19 pandemic. Here's an overview: 
Table 1: Frequency Distribution of Causes of Death Before and During the COVID-19 Pandemic at Yowari Regional Hospital, Jayapura Regency.

\begin{tabular}{|c|c|c|c|c|c|}
\hline \multirow{2}{*}{ No } & \multirow{2}{*}{ Top 10 Diseases } & \multicolumn{2}{|c|}{$\begin{array}{c}\text { Before } \\
\text { COVID-19 }\end{array}$} & \multicolumn{2}{|c|}{$\begin{array}{c}\text { During } \\
\text { COVID-19 }\end{array}$} \\
\hline & & f & $\%$ & f & $\%$ \\
\hline 1 & Heart failure & 21 & 65.6 & 28 & 50.9 \\
\hline 2 & Pulmonary TB & 4 & 12.5 & 4 & 7.3 \\
\hline 3 & Loss of consciousness & 3 & 9.4 & 5 & 9.1 \\
\hline 4 & Acute diarrhea & 1 & 3.1 & 4 & 7.3 \\
\hline 5 & Hypovolemic shock & 0 & 0.0 & 4 & 7.3 \\
\hline 6 & Malaria & 0 & 0.0 & 3 & 5.5 \\
\hline 7 & Synopsis of hepatitis & 1 & 3.1 & 2 & 3.6 \\
\hline 8 & Bronchopneumonia & 1 & 3.1 & 2 & 3.6 \\
\hline 9 & Hypertension & 1 & 3.1 & 1 & 1.8 \\
\hline 10 & Hemorrhagic shock & 0 & 0.0 & 2 & 3.6 \\
\hline & Total & 32 & 100 & 55 & 100 \\
\hline
\end{tabular}

Source: Secondary Data, 2020

Based on the results of interviews with the 4 informants, it was stated that there was no data on the top 10 causes of death in Papua Province, but if you look at specific deaths due to COVID-19, there is an indication of an increase, for example from 1 case of death at the beginning of the pandemic (March 2020) to 21 cases of death in November 2020 or an increase of 2000 percent.

Following are the results of the interviews with informants:

"The increase in mortality, in the last 3 months, started at the end of August to November 2020, the increase in cases was quite high, starting from 1 case of death to 21 deaths, specifically for COVID-19. But for the top 10 diseases, there is no explanation yet." (I4)

"The number of deaths is increasing and I am taking pictures from the community aspect if they are infected with COVID-19, but do not go to health services". (I2)

Questions on the increase in the number of deaths caused by the top 10 diseases before and during a pandemic can be explained by the following informants:
"The cause is the concept of disease in Papuans, which is different from other people's lives, where Papuans consider themselves sick if they cannot move, cannot act, so that when people experience symptoms of minor illnesses such as flu and colds, Papuans do not consider themselves sick. If it is related to the time of the COVID-19 pandemic, the concept of a disease like this will worsen the state of health services, where people are prevented from receiving prompt and appropriate services" (I1).

"Because they believe that COVID-19 is a hoax and the information they receive is not true and they do not believe it, so that people do not comply with health protocols. Thus, the transmission rate is high and, unfortunately, this transmission rate occurs in people who have congenital diseases such as diabetes and this is very quickly exposed and direct cases of death are high" (I4)

\section{Discussion}

Based on the results of the research, it is known that 
there was an increase in the number of deaths in the top 10 cases before and during the COVID-19 pandemic. This is because the knowledge and behavior of the community is still low on COVID-19.

The community considers that COVID-19 is only fake news, so it does not implement health protocols and as a result COVID-19 develops local infections or household clusters that eventually attack risk groups such as elderly people with congenital diseases such as diabetes mellitus. This situation will have an impact on the co-morbidity sufferers of COVID-19, they will quickly become serious and die. Apart from a lack of knowledge, there is also a wrong concept of illness in society, where people consider themselves not to be ill if they experience only coughs and colds. People think they're sick if they can't eat and do business, so when the disease is serious, they're going to a health service. This causes the community to be late in getting proper and quick treatment.

The cause of an increase in death cases before and during a pandemic is first, because of the community's misconception of disease, who believe that if you experience mild and moderate disease symptoms, people consider themselves not sick, so it is late for health services and late for treatment. If the illness is late for care, the disease will worsen, the patient will not be able to function, and if treatment is usually needed, treatment will become worse (band rest). ${ }^{7}$ Second, because of the group factor, because they only have mild symptoms, they are late to health care. Third, because the health facilities factor is late in catching perpetrators of COVID-19, there has been a rise in cases that would naturally have an effect on risk groups, namely elderly people and people with co-morbid. Fourth, since the population's transmission of COVID-19 is very large due to the inability to enforce health protocols, and the confusion of the community who believe that COVID-19 is not available and only hoax news is also aggravated. Transmission of risk categories, including people who have congenital disorders, is caused by a high degree of transmission.
Strategies for reducing the top 10 causes of death require diligence and community-supported strategies. In addition, it is important to have understanding, according to the informants, so that if the population is hurting immediately, health services can be immediately identified and treated so that the disease can minimize the rate of the transmission chain. In order to minimize mortality, education is necessary so that they obtain care. $80 \%$ of sufferers who died as a result of COVID-19 were due to community delays in the provision of services and the safety of workers in the provision of services. Low knowledge and understanding of health and disease among the population, according to Widyatun, makes it difficult to identify diseases that occur in society. In reality, often the disease is difficult to examine and treat. This will result in the community not having adequate health care. At this point, health education is very important. $^{8}$

Providing critical education and socialization so that people understand and want to go to health care to get adequate treatment. The second stage in the Five Prevention Stages is Particular Security or Special Protection, according to Leave and Clark. ${ }^{9}$ The special protection referred to at this stage is the protection afforded to persons or groups at risk of COVID-19 disease. This special protection is intended to ensure that at-risk groups can survive disease attacks.

Apart from socialization, the steps the government needs to take are to comprehensively fix the handling of COVID19, both surveillance, preventive and promotivation efforts involving the community through religious and religious leaders.

\section{Conclusion}

1. There has been an increase in the number of deaths in the top 10 diseases before and during COVID-19 in Papua Province.

2. The cause of the increase in mortality before and during the COVID-19 pandemic was due to the wrong concept of health and illness in the community, as well as the behavior of the community who was late in getting health services 
and thought that COVID-19 was not there.

3. The biggest cause of death is death from heart failure. Characteristics of respondents who died as a result of the top 10 diseases before COVID-19 at the Yowari Regional Hospital, Jayapura District, were 11 people aged 26-45 years (34.4\%) and 17 men (19.5\%). Meanwhile, during the COVID-19 pandemic the majority were aged 46-65 years, namely 18 people (32.7\%) and 35 men (40.2\%).

4. The regional government (Health Department) strategy in suppressing the deaths of the top 10 diseases during the COVID-19 pandemic is promotion and preventive measures.

\section{Conflict of Interest: Nil}

Source of Funding: Cenderawasih University

Ethical Clearance: Taken from Health Research Ethics Committee of Health Polytechnic of Jayapura, with the document number: 001/KEPK-J/III/2021

\section{References}

1. Kemenkes. Indonesia's COVID-19 Situation [homepage on the Internet]. 2020 [cited 2020 June 28]. Available from: https://www.kemkes.go.id.

2. Bagaskara B. The First Series of Events of COVID-19 [homepage on the Internet]. 2020 [cited 2020 Sept 20]. Available from: https:// bebas.kompas.id/baca/riset/2020/ 04/18/rangkaianperistiwa-pertama-covid-19.

3. Pusdatin. Clean and Healthy Living Behavior in Papua Province. Kemenkes; 2012.
4. Rahmawati Y. From China, Here's the Beginning of the Corona Virus Spread Around the World [homepage on the Internet]. 2020 [cited 2020 August 17]. Available from: https://www.suara. com/health/2020/04/04/183648/dari-chinabegini-cara-penyebaran-virus-corona-ke-seluruhdunia?page $=$ all.

5. CNN Indonesia. Five Complementary Diseases that Cause Death in COVID-19 Patients [homepage on the Internet]. 2020 [cited 2020 Oct 12]. Available from: https://www.cnnindonesia.com/gayahidup/20200415143127-255-493794/5-penyakitpenyerta-penyebab-kematian-pasien-covid-19

6. Dinkes Kabupaten Jayapura. Jayapura Regency Health Profile 2018. Sentani; 2019.

7. Sariana. Concept of Health and Sickness in Health Epidemiology [homepage on the Internet]. 2020 [cited 2020 Sept 18]. Available from: https://www. slideshare.net/sarianadowanx/makalah-keduakelompok-7-pengantar-epidemiologi.

8. Widyatun D. Prevention Efforts (Preventive) According to Leavel and Clark [homepage on the Internet]. 2012 [cited 2020 Sept 02]. Available from: http://jurnalbidandiah.blogspot.com/2012/05/ upaya-pencegahan-preventive-menurut.html.

9. Rizki F. Five Levels of Corona Prevention According to Leavel and Clark [homepage on the Internet]. 2020 [cited 2020 August 10]. Available from: https://madrasahdigital.co/berita/lima-levelpencegahan-corona-menurut-leavel-dan-clark/ 